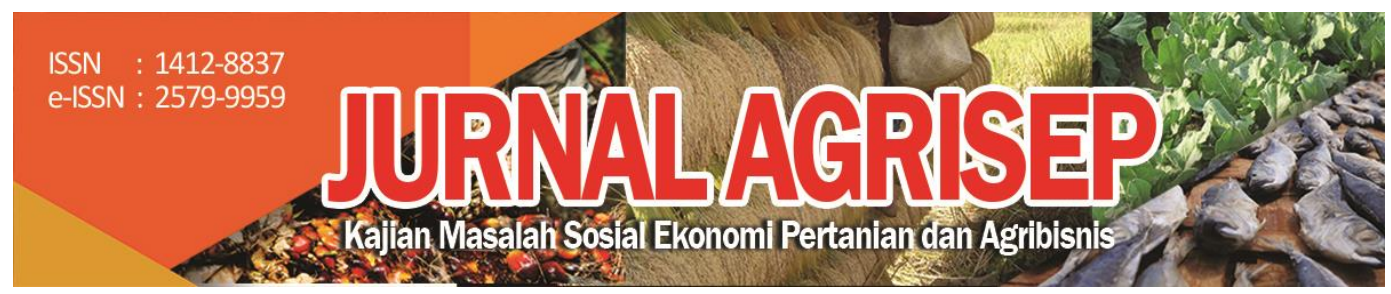

DOI: 10.31186/jagrisep.20.1.195-206

\title{
PENGARUH KEMITRAAN DAN VARIABEL LAINNYA TERHADAP KEUNTUNGAN UMK INDUSTRI MAKANAN DI INDONESIA
}

\author{
Impact of Partnership on Profit Small Micro Enterprises in Indonesia \\ Food Industry

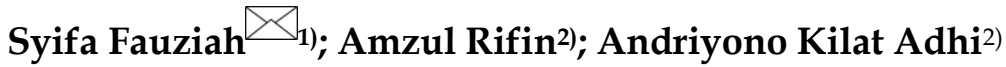 \\ ${ }^{1)}$ Mahasiswa Agribisnis FEM Institut Pertanian Bogor \\ 2)Staf Pengajar Agribisnis FEM Institut Pertanian Bogor \\ Email: syifa_fauziah52@apps.ipb.ac.id
}

\begin{abstract}
Food industry contributes a high good of labor absorption dominates in the manufacturing sector or the contribution to the total national GDP. The industry is in fact in domination by the perpetrators of Micro small and medium enterprises (MSMEs). The objectives of this research is to know the impact of partnerships and other variables against the profit of micro and small enterprises of the food industry. Multiple regression method is used to see what variables affect the profit of micro and small enterprises of the food industry entrepreneur. The results showed that dummy variables such as length of business, partnerships, education level, number of labor, the cost, the number of working hours per day, the age of the entrepreneur and the dummy sectors of the food industry influence on the profit of micro and small enterprises in the food industry. The amount of the issued capital property does not affect the profit the venture. The actors who do venture partnership is still very slightly so that the policy to encourage and develop business partnerships between the various patterns of cooperatives, small medium enterprises and large scale effort undertaken is just right and should be noted in order to sustainable.
\end{abstract}

Key words: MSMEs, partnership, profit, food industry.

\section{ABSTRAK}

Industri makanan merupakan salah satu bagian dari industri manufakturyang memiliki kontribusi yang tinggi terhadap penyerapan tenaga kerja dan terhadap pendapatan nasional. Menariknya sebagian besar usaha sektor UMKM berada pada 
sektor industri pengolahan.Penelitian ini bertujuan untuk mengetahui pengaruh dari variabel kemitraan dan variabel lainnya terhadap keuntungan usaha mikro dan kecil industri makanan di Indonesia.Metode penelitian yang digunakan adalah analisis regresi berganda, dengan 16111 responden. Hasil menunjukkan bahwa variabel kemitraan, pengalaman usaha, tingkat pendidikan, jumlah pekerja, biaya, jumlah jam kerja per hari dan usia pengusaha serta dummy sektor industri makanan mempengaruhi keuntungan terhadap usaha UMK industri makanan di Indonesia.Pelaku yang melakukan kemitraan masih sangat sedikit, sehingga kebijakan untuk mendorong dan mengembangkan berbagai pola kemitraan usaha antara koperasi, UMK dan usaha besar sudah tepat dan harus ditingkatkan lagi.

Kata Kunci: UMKM, kemitraan, keuntungan, industri makanan.

\section{PENDAHULUAN}

Usaha mikro dan kecil (UMK) memiliki peran yang penting dalam perekonomian di Indonesia terutama sebagai sumber utama kesempatan kerja dan pertumbuhan ekonomi. UMK memberikan kontribusi pada pendapatan nasional sebesar 57-60 persen dan kontribusi tenaga kerja sekitar 97 persen dari seluruh tenaga kerja yang ada (LPPI dan BI, 2015). Sementara menurut BPS (2017) kontribusi tenaga kerja UMK mencapai 59 juta orang dari 76 juta tenaga kerja yang tersedia.

Sumbangan PDB UMK bahkan terus meningkat setiap tahunnya. Seiring berjalannya waktu program pembangunan mulai bergeser dari kategori pertanian menjadi industri pengolahan. Hal ini juga didukung oleh kontribusi PDB industri pengolahan yang selalu tertinggi pada periode 2014-2019 (BPS, 2019). Sementara industri makanan dan minuman merupakan bagian dari sektor industri pengolahan yang juga memiliki kontribusi PDB nasional yang tinggi dibanding sektor industri pengolahan lainnya. Industri makanan merupakan industri yang cukup penting karena seperti yang diketahui makanan merupakan kebutuhan pokok selain sandang, dan papan. Banyaknya jumlah penduduk dan semakin bertumbuhnya penduduk juga membuat permintaan terhadap pangan semakin meningkat.

Menurut Kemenperin(2019) nilai ekspor produk makanan dan minuman nasional meningkat sebesar US 1.07 miliar pada tahun 2017. Industri makanan memberikan kontribusi yang tinggi baik dari tenaga kerja yang mendominasi di sektor pengolahansebesar 21.34 persenataupun total PDB nasional sebesar 6.14 persen pada tahun 2017. Selain itu pertumbuhan industri makanan ini juga memberikan ketertarikan tersendiri bagi para investor asing maupun dalam negeri.Menurut BPS (2017) jumlah UMK yang termasuk kategori industri pengolahan bahkan mencapai 99.04 persen. Sehingga dapat dikatakan bahwa industri pengolahan didominasi oleh sektor UMK. Selain itu jumlah tenaga kerja 
di UMKindustri pengolahan nyatanya tidak sedikit, banyak orang yang bergantung terhadap sektor ini untuk memenuhi kebutuhan sehari hari.

Skala UMK memang harus difokuskan dan diberi perhatian lebih mengingat sekarang ini kemajuan teknologi semakin pesat dan juga persaingan semakin tinggi apalagi dengan tren industri 4.0. Berdasarkan operasional usahanya sesuai dengan prinsip ekonomi umumnya setiap perusahaan pasti akan mencari keuntungan. Industri makanan yang ada di Indonesia yang didominasi oleh sektor UMK pada kenyataannya masih memiliki banyak kendala dalam menjalankan usahanya. Produksi yang meningkat diharapkan dapat meningkatkan pendapatan usaha tersebut. Para pelaku UMK cenderung mengharapkan keuntungan dari setiap usahanya untuk memenuhi kebutuhan hidup sehari-hari.

MenurutCressy dalam Casson (2008),Wardhani dan Agustina (2015) dan Butarbutar (2017) modal usaha menjadi salah satu faktor yang memengaruhi pendapatan usaha. Modal menjadi salah satu kendala dalam skala UMK. Adanya bantuan pinjaman modal ataupun kredit modal dan penetapan bunga rendah untuk biaya modal merupakan contoh upaya untuk mengurangi kendala di UMK ini. Suatu bantuan modal dapat diperoleh ketika suatu usaha tersebut mendapat bantuan atau bermitra dengan pihak lain seperti lembaga bank atau lembaga lainnya. Oleh karena itu adanya kemitraan juga dijadikan sebagai upaya untuk mengurangi kendala yang dihadapi oleh UMK.

Nyatanya memang terdapat beberapa kendala yang dihadapi oleh para pengusaha skala UMK selain biaya untuk permodalan usaha, yaitu teknologi dan pemasaran (Hamdani, 2015). Untuk mengurangi kendala yang ada pengusaha seringnya melakukan kerjasama (bermitra) dengan berbagai pihak untuk memudahkan operasional usahanya. Menurut Bygrave dalam Casson (2008) motif adanya kerjasama atau kemitraan adalah dapat mengurangi risiko dan melengkapi kemampuan, selain itu adanya kemitraan juga dapat membantu dalam kendala keuangan. Oleh karena itu dalam penelitian ini penulis ingin mengetahui bagaimana karakteristik para pelaku UMK khususnya di industri makanan dan faktor-faktor apa saja yang memengaruhi keuntungan UMK industri makanan di Indonesia.

\section{METODE PENELITIAN}

Data yang digunakan dalam penelitian ini adalah data sekunder berupa kuisioner terhadap beberapa UMK sektor pengolahan industri makanan di Indonesia. Waktu penelitian adalah bulan Januari-Mei 2019. Jumlah sampel yang digunakan pada penelitian ini sebanyak 16.111 pelaku usaha. Data sekunder yang digunakan diperoleh dari pihak terkait yang relevan dan terpercaya. Pada penelitian ini digunakan data pada tahun 2015, hal ini karena untuk memperoleh data tersebut data terbaru ada pada tahun tersebut namun 
diharapkan bisa menggambarkan juga keadaannya pada saat ini. Data yang digunakan diperoleh dari data survei UMK tahunan yaitu data dalam Klasifikasi Baku Lapangan Usaha Indonesia (KBLI) untuk industri manufaktur (kategori C) pada industri makanan dengan uraian 5-digit KBLI. Pengolahan data dilakukan secara kuantitatif. Pengolahan dilakukan dengan menggunakan software komputer yang kemudian diinterpretasikan. Selain itu dalam penentuan sampel dilakukan proses screening data. Data yang dihapus diantaranya adalah data yang memiliki residu yang sangat tinggi yaitu diluar batas sebaran normal dan juga data-data yang sekiranya menurut penulis tidak logis maupun data pencilan.Penelitian ini menggunakan model regresi berganda. Hubungan antara peubah-peubah tersebut dapat dirumuskan dalam persamaan (1) sebagai berikut:

Yd $=\mathrm{a}_{0}+\mathrm{a}_{1}$ Lamausaha $_{\mathrm{i}}+\mathrm{a}_{2}$ Pend $_{\mathrm{i}}+\mathrm{a}_{3} \mathrm{TK}_{\mathrm{i}}+\mathrm{a}_{4}$ Biaya $_{\mathrm{i}}+\mathrm{a}_{5}$ Dmitra $_{\mathrm{i}}+\mathrm{a}_{6} \mathrm{HOK}_{\mathrm{i}}+$ $\mathrm{a}_{7} \mathrm{Usia}_{\mathrm{i}}+\mathrm{a}_{8} \mathrm{Hartamodal}_{\mathrm{i}}+\mathrm{a}_{9} \mathrm{D} 1_{\mathrm{i}}+\mathrm{a}_{10} \mathrm{D} 2_{\mathrm{i}}+\mathrm{a}_{11} \mathrm{D} 3_{\mathrm{i}}+\mathrm{a}_{12} \mathrm{D} 4_{\mathrm{i}}+\mathrm{a}_{13} \mathrm{D} 5_{\mathrm{i}}+\mathrm{a}_{14} \mathrm{D} 6_{\mathrm{i}}+$ $\mathrm{a}_{15} \mathrm{D} 7_{\mathrm{i}}+\varepsilon_{\mathrm{i}}(1)$

Keterangan :

$\mathrm{Y}_{\mathrm{d}} \quad=$ Profit perusahaan

$\mathrm{a}_{0} \quad=$ Konstanta model (Intercept)

$\mathrm{a}_{1,2, \ldots 15}=$ Koefisien faktor yang mempengaruhi profit perusahaan1,2, ..15

Lamausaha = Lamanya perusahaan tersebut berdiri dari awal (tahun)

Pend = Tingkat pendidikan terakhir yang ditempuh (tahun)

TK = Banyaknya pekerja, termasuk pengusaha (orang)

Biaya = Jumlah biaya yang dikeluarkan dalam bulan terakhir produksi (rupiah)

Dmitra $=$ Pernah tidaknya menjalin kemitraan $(1=y a, 0=$ tidak $)$

HOK = Jumlah jam kerja per hari (jam)

Usia = Usia pengusaha (tahun)

Modal $=$ Nilai harta modal perusahaan (rupiah)

D1 = Dummy industri rumah potong, daging unggas dan bukanunggas

D2 = Dummy industri pengolahan ikan dan biota air lainnya

D3 = Dummy industri pengolahan buah dan sayur, kedelai

D4 = Dummy industri minyak makan, minyak goreng dan margarine

D5 = Dummy industri pengolahan susu, es krim dan sejenisnya

D6 = Dummy industri penggilingan, pengupasan padi dan biji-bijian

D7 = Dummy industri ransum dan konsentrat makanan hewan

(industri roti kue, gula dan jajanan sejenisnya digunakan sebagai pembanding)

$\mathrm{E} \quad=$ Nilai residu

$\mathrm{i} \quad=$ Jumlah responden $(1,2, \ldots \mathrm{i})$ 
Pada penelitian ini menggunakan model regresi linier berganda dengan metode kuadrat terkecil atau Ordinary Least Square (OLS) yang berfungsi untuk menduga parameter.Selain analisis regresi dilakukan juga uji asumsi klasik terhadap data-data penelitian yang meliputi pengujian multikolinearitas, heteroskedastisitas serta normalitas.

\section{HASIL DAN PEMBAHASAN}

\section{Karakteristik pemilik UMK industri makanan di Indonesia}

Karakteristik pemilik usaha terdiri dari beberapa variabel diantaranya tingkat pendidikan, usia pengusaha, lama usaha serta kemitraan. Tingkat pendidikan seseorang dapat mempengaruhi kesempatan seseorang untuk bekerja pada perusahaan ataupun sektor formal, tingkat pendidikan paling banyak yaitu tamat SD sekitar 35 persen, untuk responden yang tamat SMP dan SMA sekitar 20 persen dan 22 persen dari total yang ada.Merujuk pada Tabel 1 rata-rata tingkat pendidikan adalah 7.97 tahun atau setara dengan tingkat SMP.Adanya fenomena ini dapat diasumsikan bahwa mereka yang memilih melakukan usaha UMK ini salah satunya karena hanya memiliki ijazah dengan pendidikan formal yang rendah dibanding untuk bekerja di tempat orang lain atau bekerja kantoran. Dewi (2014) juga mengatakan bahwa tingkat pendidikan dan teknologi memiliki pengaruh positif terhadap pendapatan UMKM. Menurut Arifin dan Firmansyah (2017) tingkat pendidikan memiliki pengaruh negatif terhadap pengangguran, individu dengan tingkat pendidikan yang lebih tinggi cenderung memiliki kesempatan kerja yang lebih besar.

\section{Tabel 1 Karakteristik pemilik UMK}

\begin{tabular}{lccc}
\hline \multicolumn{1}{c}{ Variabel } & Minimum & Maksimum & Rata-rata \\
\hline Tingkat pendidikan (tahun) & 5 & 18 & 7.97 \\
Usia pengusaha (tahun) & 13 & 99 & 46.62 \\
Lama usaha (tahun) & 1 & 85 & 11.48 \\
\hline
\end{tabular}

Sumber: BPS, 2015 (diolah)

Usia pengusaha dikatakan dapat mempengaruhi keadaan dan kinerja usaha itu sendiri. Badan Pusat Statistik (BPS) mengelompokkan menjadi dua kelompok usia produktif yaitu Usia Sangat Produktif antara 15-49 tahun dan Usia Produktif antara 50-64 tahun. Keseluruhan responden yang memiliki usia yang sangat produktif mencapai sekitar 62 persen dan usia yang produktif sekitar 32 persen, sehinggasekitar 94 persen pengusaha yang ada di UMK pada industri makanan adalah para pengusaha yang berada pada usia yang produktif atau dalam rentang usia 15-64 tahun. Merujuk Tabel 1usia minimum pengusaha 
adalah 13 tahun, dimana sebenarnya ini masih belum termasuk umur produktif untuk bekerja.

Pengalaman usaha adalah salah satu faktor penting agar usaha dapat berjalan dengan lancar, adanya pengalaman yang lebih banyak dapat memilih dan mengambil keputusan lebih cepat dan tepat. Sementara Tabel 1 menunjukkan rata-rata lamanya usaha adalah sekitar 11.48 tahun.Furqon (2018) mengatakan bahwa lamanya usaha memiliki pengaruh yang positif terhadap pendapatan usaha UMKM. Lamanya usaha dapat menimbulkan pengalaman usaha yang dapat memengaruhi seseorang dalam bertingkah laku dan mengambil keputusan. Seseorang yang memiliki usaha lebih lama cenderung lebih memahami usahanya sehingga usahanya dapat lebih efisien dan keuntungan yang lebih besar.

Kemitraan merupakan salah satu faktor yang dapat mendukung jalannya suatu usaha. Dengan adanya kemitraan diharapkan segala urusan dalam usaha dapat menjadi lebih mudah. UMK yang melakukan atau pernah menjalin kemitraan masih sangat sedikit bahkan tidak sampai sepuluh persen.Menurut Herawati (2011) kemitraan yang dilakukan antara UMK dengan usaha besar dapat menghasilkan win-win solution yang dapat berguna bagi masyarakat namun tentunya harus didasari dengan prinsip yang berlaku seperti komitmen dan transparan serta kejujuran antara pihak yang bermitra dan dikembangkan secara rasional. Adanya kemitraan sangat mempengaruhi pendapatan yang dihasilkan dari suatu usaha. Namun berdasarkan data yang diperoleh usaha UMK industri makanan yang ada di Indonesia sebagian besar tidak bermitra dalam menjalankan usahanya.

\section{Karakteristik UMK industri makanan di Indonesia}

Karakteristik UMK terdiri dari beberapa variabel diantaranya sektor industri, jumlah pekerja, jam kerja per hari, biaya dan keuntungan yang diterima.

Adanya Kementrian Koperasi dan Usaha Kecil Menengah diharapkan dapat meningkatkan kinerja dan memperbaiki kondisi para pengusaha UMK itu sendiri.Berdasarkan data penelitian responden adalah pengusaha UMK yang bergerak di bidang industri makanan, yang dibagi lagi menjadi delapan sektor berdasarkan kode 5-digit KBLI yang ada, delapan sektor tersebut diantaranya disajikan pada Tabel 2. Merujuk Tabel 2 dapat dilihat bahwa UMK industri makanan yang ada di Indonesia didominasi oleh para pengusaha dengan kode digit 107 yaitu usaha seperti roti, kue kue basah dan produk makanan sejenisnya. 
Tabel 2 Delapan sektor UMK industri makanan

\begin{tabular}{|c|c|c|c|}
\hline $\begin{array}{l}\text { Kode } \\
\text { digit }\end{array}$ & Keterangan & $\begin{array}{l}\text { Jumlah } \\
\text { usaha }\end{array}$ & $\begin{array}{c}\text { Persentase } \\
(\%)\end{array}$ \\
\hline 101 & $\begin{array}{l}\text { Industri rumah potong dan pengolahan } \\
\text { daging unggas dan bukan unggas }\end{array}$ & 89 & 0,55 \\
\hline 102 & $\begin{array}{l}\text { Industri pengolahan ikan dan biota air } \\
\text { lainnya }\end{array}$ & 779 & 4,83 \\
\hline 103 & $\begin{array}{l}\text { Industri pengolahan buah dan sayur, } \\
\text { kedelai }\end{array}$ & 1.319 & 8,18 \\
\hline 104 & $\begin{array}{l}\text { Industri minyak makan, minyak goreng, } \\
\text { margarine }\end{array}$ & 1.043 & 6,47 \\
\hline 105 & $\begin{array}{l}\text { Industri pengolahan susu, es krim dan } \\
\text { sejenisnya }\end{array}$ & 277 & 1,71 \\
\hline 106 & $\begin{array}{l}\text { Industri penggilingan, pengupasan padi } \\
\text { dan biji-bijian }\end{array}$ & 648 & 4,02 \\
\hline 107 & $\begin{array}{l}\text { Industri roti kue, gula dan jajanan } \\
\text { sejenisnya }\end{array}$ & 11.947 & 74,15 \\
\hline 108 & $\begin{array}{l}\text { Industri ransum dan konsentrat } \\
\text { makanan hewan }\end{array}$ & 9 & 0,05 \\
\hline Total & & 16.111 & 100,00 \\
\hline
\end{tabular}

Sumber : BPS, 2015 (diolah)

Tenaga kerja merupakan input penting dalam suatu usaha. Pada UMK industri makanan ini sebanyak 45 persen dari responden yang ada hanya menggunakan 2 orang tenaga kerja (termasuk pemilik usaha). Sementara untuk tenaga kerja yang berjumlah satu, berarti pengusaha mengerjakan usahanya sendiri juga cukup banyak yaitu sekitar 37 persen, merujuk Tabel 3 rata-rata jumlah pekerja adalah 2.01 orang.Penentuan tenaga kerja dalam UMK yang skala usahanya masih cenderung kecil biasanya memang berdasarkan jumlah produksi dan modal yang dimiliki oleh pengusaha tersebut. Sehingga untuk UMK tidak banyak pelaku usaha yang memperkerjakan pekerjapada usahanya terutama dalam jumlah yang banyak. Sementara menurut Artini (2019) jumlah pekerjamemiliki pengaruh yang positif terhadap pendapatan sebuah UMKM.

\section{Tabel 3 Karakteristik UMK Industri Makanan}

\begin{tabular}{lccc}
\hline \multicolumn{1}{c}{ Variabel } & Minimum & Maksimum & Rata-rata \\
\hline Jumlah pekerja (orang) & 1 & 19 & 2.01 \\
Jam kerja per hari (jam) & 1 & 24 & 5.53 \\
Biaya (ribu rupiah) & 36 & 275000 & 8530 \\
Keuntungan (ribu rupiah) & -1950 & 35750 & 1816 \\
\hline
\end{tabular}

Sumber: BPS, 2015 (diolah) 
Banyaknya jam kerja yang digunakan pada setiap perusahaan tentunya berbeda beda. Sebagian dari responden bekerja sekitar lima jam per hari, lalu yang bekerja sekitar 6-8 jam per hari yaitu sekitar 39 persen, hanya sekitar 1 persen perusahaan yang pekerjanya bekerja lebih dari 12 jam per hari. Tabel 3 menunjukkan bahwa rata-rata pengusaha bekerja sekitar 5.53 jam setiap harinya. Sementara menurut Maheswara et al (2016) variabel jam kerja berpengaruh positif tidak signifikan terhadap pendapatan usaha. Dalam hal ini berarti seseorang yang memiliki jam kerja yang lebih banyak belum tentu akan menghasilkan pendapatan yang lebih banyak.

Biaya yang dikeluarkan sangat mempengaruhi jalannya suatu usaha.Pada UMK industri makanan di Indonesia sekitar 39 persen pengusaha mengeluarkan biaya sekitar satu sampai tiga juta per bulannya. Biaya yang dikeluarkan ini merupakan keseluruhan biaya yang meliputi pembayaran sewa untuk tenaga kerja, dan biaya lainnya untuk kepentingan usaha seperti pembelian bahan baku, dan penggunaan air atau listrik.

Sebagian besar pelaku UMK pada penelitian ini memiliki keuntungan yang cukup rendah yaitu kurang dari satu juta setiap bulannya, padahal dapat diketahui bahwa pengeluaran keluarga per bulan jauh lebih banyak dari profit yang diterimanya. Keuntungan yang diterima oleh para pelaku usaha sekitar satu sampai tiga juta per bulan ada sekitar 37 persen, masih sedikit pengusaha yang dapat memperoleh keuntungan lebih dari 10 juta perbulannya.Merujuk Tabel 3 rata-rata keuntungan yang diperoleh setiap bulannya adalah sekitar 1,8 juta. Tinggi rendahnya profit yang diterima juga dapat disebabkan oleh beberapa hal yang mempengaruhinya dimana beberapa faktornya dapat dilihat pada penelitian ini.

\section{Faktor yang Memengaruhi Keuntungan UMK Pada Industri Makanan di Indonesia}

Berdasarkan hasil terdapat beberapa variabel yang berpengaruh terhadap keuntungan UMK industri makanan di Indonesia. Merujuk padaTabel 4 variabel yang berpengaruh positif signifikan pada taraf nyata lima persen yaitu tingkat pendidikan, jumlah pekerja, jumlah jam kerja, dummy kemitraan, biaya yang dikeluarkan, dan banyaknya jam kerja per hari selain itu dummy kode-digit sektor industri makanan juga berpengaruh signifikan kecuali untuk D2 (dummy dengan kode-digit 102) yang tidak signifikan dan D6 (dummy dengan kode-digit 106) yang signifikan pada taraf sepuluh persen. Selain itu variabel usia pengusaha dan lama usaha juga berpengaruh nyata pada taraf sepuluh persen. Dummy industri 101, 103 dan 108 memiliki koefisien positif yang berarti keuntungan yang diperoleh lebih besar dibandingkan Dummy pembandingnya (107). 
Tabel 4 Hasil uji signifikansi

\begin{tabular}{lccc}
\hline \multicolumn{1}{c}{ Variabel } & Koefisien & P-value & \multicolumn{1}{c}{ VIF } \\
\hline Lama usaha & $1797.77^{*}$ & 0.007 & 1.10 \\
Tingkat pendidikan & $52113.99^{* * *}$ & 0.000 & 1.09 \\
Jumlah pekerja & $156610.90^{* * *}$ & 0.000 & 1.25 \\
Biaya yang dikeluarkan & $0.15^{* * *}$ & 0.000 & 1.25 \\
Dummy kemitraan & $243364.10^{* * *}$ & 0.000 & 1.02 \\
Jumlah jam kerja per hari & $47751.27^{* * *}$ & 0.000 & 1.16 \\
Umur pengusaha & $-1418.17^{*}$ & 0.084 & 1.00 \\
Harta modal & -0.00 & 0.127 & 1.00 \\
Dummy industri 101 & $328650.10^{* *}$ & 0.027 & 1.01 \\
Dummy industri 102 & -60169.60 & 0.219 & 1.03 \\
Dummy industri 103 & $222016.50^{* * *}$ & 0.000 & 1.07 \\
Dummy industri 104 & $-168199.60^{* * *}$ & 0.000 & 1.12 \\
Dummy industri 105 & $-208935.50^{* * *}$ & 0.001 & 1.00 \\
Dummy industri 106 & $-189381.80^{*}$ & 0.085 & 1.05 \\
Dummy industri 108 & $1164423^{* *}$ & 0.019 & 1.00 \\
\hline
\end{tabular}

Keterangan :

*** berpengaruh signifikan pada $1 \%$

** berpengaruh signifikan pada $5 \%$

* berpengaruh signifikan pada $10 \%$

Sumber: BPS, 2015 (diolah)

Modal usaha, tenaga kerja dan lamanya usaha berpengaruh terhadap pendapatan yang diterima suatu usaha, faktor yang paling dominan adalah faktor tenaga kerja yang berpengaruh secara positif signifikan(Butarbutar, 2017). Sementara hasil uji asumsi klasik dari penelitian ini untuk uji heteroskedastisitas dilakukan pengujian menggunakan robust sehingga asumsi data homoskedastisitas telah terpenuhi, selain itu untuk multikolinear dapat dilihat berdasarkan Tabel 4dimana seluruh variabel memiliki nilai vif $<10$ sehingga data tidak mengandung multikolinear.

\section{Pengaruh Kemitraan terhadap Keuntungan UMKIndustri Makanan di Indonesia}

Model persamaan keuntungan UMK pada industri makanan menunjukkan bahwa adanya kemitraan memiliki pengaruh nyata yang positif terhadap keuntungan yang diterima oleh para pengusaha. Namun sangat disayangkan bahwa pengusaha UMK industri makanan masih sedikit yang melakukan kemitraan. Padahal adanya kemitraan dapat berdampak baik untuk usaha tersebut dan bukan hanya dilihat dari sisi pendapatan yang meningkat saja.Berdasarkan hasil yang diperoleh responden yang bermitra dengan pihak lain hanyalah sekitar enam persen dari total sekitar 16111 responden yang 
digunakan. Selain itu hanya sekitar 4.28 persen responden yang menjadi anggota koperasi.Namun nyatanya sedikitnya jumlah responden yang bermitra ini mampu memperoleh hasil yang signifikan pada taraf nyata satu persen, hal ini dapat diartikan bahwa adanya kemitraan memang berpengaruh terhadap keuntungan yang diterima oleh pengusaha.

Berdasarkan Tabel 5 perusahaan yang bermitradi dominasi oleh para pelaku usaha di sektor industri roti, kue gula dan jajanan sejenisnya. Selain itu, jika dilihat dari sisi lain UMK industri makanan yang melakukan kemitraan nyatanya mendapatkan keuntungan rata-rata sekitar Rp. 2519459,- sedangkan usaha yang tidak melakukan kemitraan mendapatkan keuntungan rata-rata sekitar Rp. 1623 352,-. Dalam hal ini dapat dilihat bahwa usaha yang melakukan kemitraan, walaupun jumlahnya jauh lebih sedikit namun hasil keuntungan rata-ratanya lebih tinggi dibandingkan keuntungan rata-rata yang diperoleh oleh UMK industri makanan yang tidak melakukan kemitraan. Jenis kemitraan yang dilakukan diantaranya bantuan berupa modal, bahan baku dan kemudahan pemasaran. Sementara sebanyak 33 persen responden mengaku bahwa kesulitan utama dalam usaha adalah terkait modal usaha.

Menurut Urfa dan Handayani et al (2014) dan Pratama (2013) adanya kemitraan berupa bantuan modal serta kegiatan pelatihan dianggap berhasil dalam meningkatkan jumlah produksi dan pendapatan suatu usaha. Hal ini sejalan denganSusantiet al (2014) juga mengatakan adanya kemitraan dapat meningkatkan pendapatan usahatani lebih baik dibandingkan non mitra.

Tabel 5 Sebaran industri yang melakukan kemitraan

\begin{tabular}{lcc}
\hline \multicolumn{1}{c}{ Jenis Industri } & Jumlah usaha & $\begin{array}{c}\text { Persentase } \\
(\%)\end{array}$ \\
\hline Rumah potong dan pengolahan daging & 2 & 0,22 \\
Pengolahan ikan & 80 & 8,88 \\
Pengolahan buah dan sayur, kedelai & 96 & 10,67 \\
Minyak makan, minyak goreng, margarine & 25 & 2,78 \\
Pengolahan susu, es krim dan sejenisnya & 17 & 1,89 \\
Penggilingan, pengupasan padi dan biji-bijian & 20 & 2,22 \\
Roti kue, gula dan jajanan sejenisnya & 660 & 73,33 \\
Ransum dan konsentrat makanan hewan & 0 & 0,00 \\
\hline Total & 900 & 100,00 \\
\hline
\end{tabular}

Sumber: BPS, 2015 (diolah)

\section{Simpulan}

\section{SIMPULAN DAN SARAN}

Adanya kemitraan memiliki pengaruh signifikan terhadap tingkat keuntungan yang diperoleh pada UMK industri makanan di Indonesia. Keuntungan rata-rata yang diperoleh oleh usaha yang bermitra lebih tinggi 
dibanding usaha yang tidak bermitra.Selain itu beberapa variabel yang signifikan terhadap keuntungan diantaranya variabel tingkat pendidikan, jumlah pekerja, biaya yang dikeluarkan, jumlah jam kerja perhari, lama usaha, usia pengusaha serta dummy industridengan kode digit 101, 103, 104, 105, 108.

\section{Saran}

Untuk meningkatkan keuntungan usaha khususnya pada UMKindustri makanan dapat dilihat dari segi kemitraan. Variabel kemitraan berpengaruh kuat signifikan terhadap keuntungan UMK industri makanan di Indonesia.Padahal pelaku yang melakukan kemitraan masih sangat sedikit, sehingga kebijakan untuk mendorong dan mengembangkan berbagai pola kemitraan usaha antara koperasi, UMK dan usaha besar sudah tepat dan harus ditingkatkan lagi agar UMK dapat berkembang dengan baik.

\section{DAFTAR PUSTAKA}

Arifin S, Firmansyah. 2017. Pengaruh tingkat pendidikan dan kesempatan kerja terhadap pengangguran di Provinsi Banten. Jurnal Ekonomi-Qu. 7(2).

Artini NR. 2019. Analisis faktor-faktor yang mempengaruhi pendapatan UMKM di Kabupaten Tabanan. Jurnal Unmas Mataram. 13(1): 71 -77.

Badan Pusat Statistik (BPS). 2014. Tabel perkembangan UMKM pada periode 1997-2013. [diakses 29 januari 2020].

.2015. Kasus Batas KBLI Kelompok Usaha Industri Manufaktur Survei Industri Mikro dan Kecil Tahunan Tahun 2015. Jakarta (ID): Badan Pusat Statistik.

2017. Data Hasil Pendaftaran Usaha atau Perusahaan Sensus Ekonomi 2016. Jakarta: Badan Pusat Statistik.

2018. Perkembangan Indeks Produksi Triwulanan Industri Mikro dan Kecil 2016-2018. Jakarta: Badan Pusat Statistik.

. 2019. Analisis Hasil Sensus Ekonomi 2016 Lanjutan Analisis Daya Saing Usaha Industri Pengolahan. Jakarta: Badan Pusat Statistik.

Potensi Peningkatan Kinerja Usaha Mikro Kecil. Jakarta: Badan Pusat Statistik.

Butarbutar GR. 2017. Analisis faktor faktor yang memengaruhi pendapatan usaha industri makanan khas di Kota Tebing Tinggi. JOM Fekon. 4(1): 619-633

Casson M, et.al. 2008. The Oxford Handbook of Entrepreneurship. OxfordUniversity Press. 
Dewi PM. 2014. Pengaruh modal, tingkat pendidikan dan teknologi terhadap pendapatan usaha mikro kecil dan menengah (UMKM) di kawasan Imam Bonjol Denpasar Barat. E-Jurnal Ekonomi Pembangunan Universitas Udayana. 3(12): 576- 585.

Furqon DF. 2018. Pengaruh modal usaha, lama usaha dan sikap kewirausahaan terhadap pendapatan pengusaha lanting di Lemah Duwur, KecamatanKuwarasan, Kabupaten Kebumen. Jurnal Pendidikan dan Ekonomi. 7(1):51-59.

Hamdani M. 2015. Dukungan perusahaan dalam pengembangan UMKM berbasis program corporate social responsibility. Seminar Nasional Kewirausahaan dan Inovasi Bisnis. Jakarta (ID): Universitas Tarumanegara.

Herawati AR. 2011. Sistem kemitraan usaha mikro kecil menengah (UMKM) usaha besar dengan pemodelan system archetype. Disertasi. Jakarta(ID): Universitas Indonesia.

Kementerian Perindustrian (Kemenperin). 2019. Siaran pers kontribusi industri makanan dan minuman mencapai 34.17 persen. [27 Mei 2019]

Lembaga Pengembangan Perbankan Indonesia dan Bank Indonesia (LPPI dan BI). 2015. Profil bisnis usaha mikro, kecil, dan menengah (UMKM). Jakarta (ID):Bank Indonesia.

Maheswara AANG, Setiawina ND, Saskara IAN. 2016. Analisis faktorfaktoryang mempengaruhi pendapatan UKM sektor perdagangan di Kota Denpasar. E-Jurnal Ekonomi dan Bisnis Universitas Udayana. 5(12):4271-4298.

Pratama MA. 2013. Analisis efektivitas corporate social responsibility dalam program kemitraan badan usaha milik negara: studi kasus pada perkembangan UMKM mitra binaan PT Perkebunan Nusantara VII Unit Usaha Rejosari. Jurnal Natapraja. 1(1): 105-113.

Susanti, Kusnadi N, Rachmina D. 2014. Pengaruh kemitraan terhadap produksi dan pendapatan usahatani sayuran di Kabupaten Bogor. Tesis. Bogor (ID): Institut Pertanian Bogor.

Urfa VH, Handayani SR, Hidayat RR. 2013. Efektivitas penggunaan kredit program kemitraan BUMN terhadap kinerja UMKM: studi kasus pada program kemitraan PT Telekomunikasi Indonesia, Tbk Sub Arae Malang untuk industri Sari Apel Brosem Kota Batu. Jurnal Administrasi Bisnis. 6(1):1- 10.

Wardhani RS, Agustina Y. Analisis faktor faktor yang memengaruhi daya saing pada sentra industri makanan khas Bangka di Kota Pangkal Pinang. Jurnal Akuntansi Universitas Jember. Hal:64-96. 